\title{
Universiteit
}

Leiden

The Netherlands

\section{Introduction: Ruins in Contemporary Greek Literature, Art, Cinema, and Public Space}

Boletsi, M.; Celik Rappas, I.A.

\section{Citation}

Boletsi, M., \& Celik Rappas, I. A. (2020). Introduction: Ruins in Contemporary Greek Literature, Art, Cinema, and Public Space. Journal Of Modern Greek Studies, 38(2), vii-xxv. doi:10.1353/mgs.2020.0020

Version: $\quad$ Publisher's Version

License: $\quad$ Licensed under Article 25fa Copyright Act/Law (Amendment Taverne)

Downloaded from: https://hdl.handle.net/1887/3200997

Note: To cite this publication please use the final published version (if applicable). 


\section{PROJECT MUSE}

Introduction: Ruins in Contemporary Greek Literature, Art, Cinema, and Public Space

Maria Boletsi, Ipek A. Celik Rappas

Journal of Modern Greek Studies, Volume 38, Number 2, October 2020, pp. vii-xxv (Article)

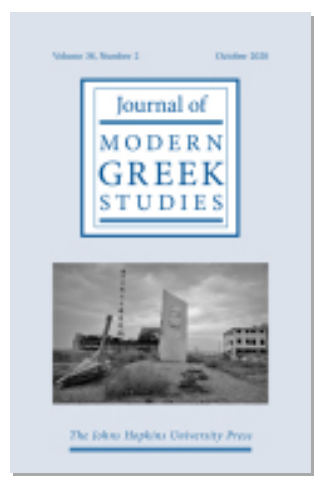

Published by Johns Hopkins University Press

DOI: https://doi.org/10.1353/mgs.2020.0020

$\Rightarrow$ For additional information about this article https://muse.jhu.edu/article/765947 


\title{
Introduction: Ruins in Contemporary Greek Literature, Art, Cinema, and Public Space
}

\author{
Maria Boletsi and Ipek A. Celik Rappas
}

Panos Koutras's film Eeví (Xenia, 2014) provokes a debate about the social value of ruins. In this travel and coming-of-age narrative, the title stands for the "hospitality" provided by a dilapidated hotel, in the ruins of which the Greek-Albanian characters Ody and his brother Dany find refuge. In an earlier scene on Ody's balcony overlooking the city of Athens, Dany points into the distance and asks, "Is that the Acropolis?" Ody listlessly acknowledges that it is, and they continue a heated discussion about their family's past. While the ancient ruin in the capital becomes a background against which the characters fight over their memories, the modern ruin on the periphery-the hotelbecomes the setting for reconciliation and for dreams of a possible future. In the middle of the film, the heroes reach the ruined hotel-the scene was shot in the Kozani Xenia hotel, one of the Xenia hotels built by the Greek National Tourism Organization and an epitome of the modernist architecture of the 1960s - where they finally bond, drink, and dance to an Italian song from the 1970s. The ruined hotel invites an alternative view of ruins: instead of representing a distant eternal uninhabited beauty, ruins here are an inhabited space that accommodates, and is re-made by, the so-called xenoi, the "foreigners." The former luxury hotel, in its peripheral and abandoned state, provides refuge from the xenophobic and homophobic attacks that have threatened the characters on their journey thus far.

Iakovos Panagopoulos argues that the name of the hotel, Xenia, is a reference to xenophobia rather than philoxenia (hospitality), "as the heroes are located in a hostile place, which is strongly illustrated in the abandonment of the hotel and the isolation of heroes in it" $(2017,59)$. The abandonment and isolation of this modernist architectural ruin, however, need not be seen as representing hostility, especially in light of the amount of relief, diversion, and ease the ruin provides both for the protagonists and for the narrative itself. 
For Dimitris Papanikolaou, the Xenia hotel is a space of "mending" for the characters and, more importantly, a "queer" space of hope that allows them to "make that space together, nominating it with their bodies. This is how the symbol of Greece's abandonment and noxious debt is turned into a queer refuge-with a possible future" (forthcoming [b]). ${ }^{1}$ According to Papanikolaou, this ruined space becomes the setting for a new meaning of hospitality, and also of citizenship, to emerge. In the Xenia hotel, hospitality and citizenship are not defined and offered by the state, but by "what bodies make, when bodies orient towards one another" (ibid.). Reflecting on the function of the same ruined site in the film, Stathis Gourgouris notes that, in the characters' attempt to be liberated from the "debilitating dialectic of being xenoi (foreigners) at home without a home," the ruined hotel (and the film itself that bears that hotel's name) becomes a space to accommodate their "foreignness"- not only a space of hospitality but also one that calls for a new emancipatory identity, detached from "the binds of their inherited filiation" (2019, 534-535).

This special section aims to trace such alternative meanings and operations of ruins and ruined spaces in contemporary Greek culture, literature, film, memoirs, art, and public space. It thereby draws attention to cases that revise, complicate, thwart, or defamiliarize common valuations of (Greek) ruins as burdens of the past, signifiers of loss, failure, and nostalgia, or sources of national pride that are idealized, fetishized, or commodified. The contributing authors revisit ruins of the remote and recent past, as well as new, contemporary ruins in Greece, both in urban centers and on the periphery. They approach ruins as foreign objects with unsettled meanings that haunt and are haunted by the contemporary moment, opening up to debate our assumed familiarity with ruins as spaces of "inherited filiation" (Gourgouris $2019,535)$. The contributions also inquire into how ruins can become productive materialities or contested spaces, partaking in unexpected encounters and critical debates-be they the ruins of the Parthenon in literary imagination, as in Athina Markopoulou's article, a dilapidated building in central Athens that became the subject of an artwork, as explored in Kelley Tialiou's contribution, the ruins of the Greek capital itself in the photographs and texts scrutinized in Eleni Papargyriou's work, the abandoned and ruined villages in the Prespa lakes region that inspire memoirs and films, as analyzed in Helen Vatsikopoulos's and Dimitris Papadopoulos's essays, or the Ottoman heritage sites whose historical and literary fates are examined in Faidon Moudopoulos-Athanasiou's and Maria Akritidou's contributions, respectively. Rather than being stagnant sites of idealization, fetishization, decay, or forgetfulness, ruins in these articles emerge as dynamic assemblages in the process of ruination. At times they 
are "abject matter ... assumed through an act of violation" (Navaro-Yashin $2009,5)$ in the aftermath of war or civil strife, but they also turn into "affective spaces" for those who inhabit and "symbolize them, interpret them, politicize them, understand them, project their subjective conflicts onto them, remember them, try to forget them, historicize them, and so on" (Navaro-Yashin 2009, 15). As such, they are places in a process of becoming that are being made and re-made through practices of re-appropriation, as well as re-imagining and re-signification, in memorials, artworks, films, and literature.

This approach to ruins is in conversation with Ann Laura Stoler's account of ruins as "sites that condense alternative senses of history" $(2008,194)$. Instead of characterizing ruins "as memorialized and large-scale monumental 'leftovers' or relics," Stoler pleads for a vision of ruins as "what people are 'left with," that is, "the social afterlife of structures, sensibilities, and things," and sites that call for constant reinterpretation (ibid.). Along the same lines, Rebecca Bryant describes ruins as "remains of history" that become "history's remainders, pieces of a past that do not fit, and hence reminders of a past that is unfinished and so capable of molding the present in new and unexpected ways" (2010, 149). Even though Stoler and Bryant write about the effects of colonial rule and about ruins in conflict zones, respectively, their conception of ruins resonates in the Greek context, especially in light of the recent economic crisis and its material effects that "reside in the corroded hollows of landscapes, in the gutted infrastructures of segregated cityscapes and in the microecologies of matter and mind" (Stoler 2008, 194).

Along similar lines, this special section moves away from nostalgic ruminations on "inert remains" and their aesthetics, focusing instead "on their vital refiguration" (ibid.) or on the ways these sites and objects of an "unfinished" past shape "the present in new and unexpected ways" (Bryant 2010, 149). The refigurations of ruins that take center stage here span a wide range of media and cultural forms and are approached from diverse (inter)disciplinary perspectives, including literary studies, contemporary art, photography and visual studies, archeology, history, and memory studies. They involve ancient ruins that are central to the national imagination and identity (such as the Parthenon), ruins of contested chapters of modern Greek history (such as the Greek Civil War), marginalized ruins of Others in the Greek space (such as Ottoman remains), contemporary urban ruins, and also ruins situated on the periphery, like the Prespa region and the Xenia Hotel in Kozani. The contributions to this section remind us that ruins are themselves media, both in the original sense of the word, as carriers of things and affects-past narratives, cultural memories, trauma, loss, unrealized futures - and as heavily mediated objects 
and spaces. This section therefore addresses ruins both in their material histories and archaeologies and in their multiple mediations in photography, film, literature, and conceptual art.

\section{Ancient ruins: From cultural capital to the crisis of capital}

The social, affective, and symbolic functions of ancient ruins in the Greek national imaginary, as well as in the construction of Hellas in the European imagination, have received much scholarly attention (e.g., Leontis 1995; Avlami 2000; Yalouri 2001; Hamilakis 2007, 2016; Damaskos and Plantzos 2008; Zacharia 2008; Tziovas 2014; Plantzos 2016, 2019; Hanink 2017). As Artemis Leontis succinctly puts it, Hellas "is a topos of architectural and sculptural ruins" (1995, 40). Ruins have thus been explored as material traces from the Hellenic past, "essential emblems, images, and material landmarks that define the topos of the nation" (Hamilakis 2007, 16).

In the late eighteenth century, crumbling faux-Classical temples appeared in European paintings and private gardens, encouraging nostalgic musings on the aesthetics of decay (DeSilvey and Edensor 2012, 466). The Greek Revival movement in architecture and the decorative arts, as well as the so-called rediscovery of Greece in Romantic literature and scholarship, gave shape to Hellas in the European imaginary as "a heterotopia, a space set apart precisely because it contains classical ruins" (Leontis 1995, 44-45). These ruins, especially in the case of the Acropolis, were literally and metaphorically appropriated by the West for its own symbolic and material purposes (Leontis 1995; Yalouri 2001). In the same period, as Hellas took shape in the European imagination as the origin of civilization, ruins metaphorically also came to denote the rift between the classical ideal and modern Greek reality, yielding an image of modern Greece as-in a verse from Lord Byron's Childe Harold's Pilgrimage-a "sad relic of departed worth" (Byron [1812-1818] 2004, canto 2, stanza 73; cf. Liakos $2008,208)$. This supposed discontinuity was compatible with the notion of revival that was central to the European construction of Hellenism. As Antonis Liakos writes, "The concept of 'relics' omnipresent in the early modern and the Romantic culture implies a moment of death, of mourning, and of melancholy, but also gives the beat for the successive renaissances, revivals, re-evolutions, re-formations, and all of the European cultural phenomena characterized by concepts of a new beginning" $(2008,208)$. Hellenism was understood by European Philhellenes "as the revival of the ancient in modern Greece" (Liakos 2008, 207-208). 
The narrative of revival became central to the foundation of the Modern Greek state in the nineteenth century. Ruins were seen as "proof of the connection between modern Greek people and their ancestors" (Hanink 2017, 223). As Liakos puts it, the national narrative was premised on the "incorporation of antiquity" not only as the "beginning" but as the actual "object of this narrative": "For Greeks, to feel as national subjects means to internalize their relationship with ancient Greece" (2008, 204-205). Sculptural ruins and antiquities do not figure as mere "representations of ancestors," Yannis Hamilakis argues, but are regularly "described in an anthropomorphic, empathic language" as "living members of the national body" $(2007,32)$. In the second half of the nineteenth century, as the national historical narrative evolved from the idea of revival to that of the continuity of the Greek nation from ancient to modern times, especially under the influence of the work of "national historian" Konstantinos Paparrigopoulos, ${ }^{2}$ the prominent presence of ruins from different historical periods in the Greek landscape lent support to this narrative.

If "the culture of ruins" is Greece's "most recognizable modern signature" (Leontis 1995, 66), for modern Greeks this culture has been perceived as both "an asset and a burden" (Tziovas 2014, 1) - a source of national self-determination and pride, as well as a constant reminder of the chasm between the classical ideal and modern Greek reality. The latter function of ancient ruins was given new intensity in the years of the Greek debt crisis, during which the heterotopia of Greek ruins was rekindled, redefined, and contested again. Thus, the association of material ruins with the cultural capital of the classical heritage was intertwined with a metaphorical association of ruins with the consequences of the economic crisis: a shift from cultural capital to the crisis of capital. The narrative of the difference between the allegedly decadent present-day Greeks and their ancestors was foregrounded once more by the international press in a distant echo of the disillusionment of early European travelers with modern Greeks (Hamilakis 2016, 230; Hanink 2017, 198). ${ }^{3}$ Headlines, articles, and reports about the crisis in foreign media ridiculed Greeks "as the unworthy descendants of their illustrious ancestors" (Hanink 2017, 199). In European media, the use of classical tropes that described Greece as Europe's "Achilles heel" or a "Trojan horse" or labeled the situation as a "modern Greek tragedy" resulted in conceptualizing and "quarantining Greece as a form of economic, political and cultural ruin metastasizing within the European body politic" (Gumpert 2017, 31). Cartoons and magazine covers mobilized images of ancient ruins, broken marbles, the Acropolis on the brink of collapse, or amputated statues as "a way of poking fun at the shambles of [Greece's] modern economy, the country's newest debris" (Hanink 2017, 224) and "suggesting 
that the country has disgraced its patrimony" (Talalay 2013, 269). Through an "iconographic blending ... of ancient and modern remnants," classical ruins were used as visual metaphors for Greece's financial collapse and the ruination that the crisis brought about (Hamilakis 2016, 238). ${ }^{4}$

In cartoons that satirized the crisis, the frequent figuration of "mutilation and fragmentation (of statues and temples, of bodies, of the nation)," as Hamilakis observes, is possibly suggestive of "a broader, even global fascination with the remnants and traces of violence" $(2016,237)$ - a fascination also confirmed by widespread practices of "dark tourism" or "thanatotourism" in crisis-stricken Greece (Tzanelli and Korstanje 2016; Hanink 2017, 228-229). Moreover, the metaphorical link between classical ruins and the ruins of the crisis transferred the negative connotations of the latter to the former: ancient ruins were invested with connotations of "fallen grandeur, of complete and irreversible loss, and perhaps also of negligence on the part of their present-day stewards" (Hamilakis 2016, 237; cf. Talalay 2013). This perception of classical ruins in present-day Greece was in line with the underlying self-perception of Western Europeans as the "rightful owners of the classical legacy" (Hamilakis 2016, 238), affirming Western European crypto-colonial attitudes toward Greece that have been present throughout the nation's modern history (Herzfeld 2002).

\section{Contemporary lives of ruins}

If international responses to the crisis projected stereotypical imagery of ancient ruins as metaphors for Greece's financial ruination, domestic Greek cultural production in the past decade has mobilized a much richer palette of ruins - from ancient to contemporary - to capture a radically changed reality and to renegotiate the present's relationship to the past and the future. Ruins have often been framed through the tropes of trauma and melancholia or enveloped in a sense of escapism, defeat, and disillusionment with failed nationalist and modernist visions, but recent cultural production has also engaged in a radical rethinking of the past and of the functions of ruins in the present. Dimitris Papanikolaou coined the term "archive trouble" (2011) to address this "iconoclastic return to the past" $(2017,45)$ by writers, artists, performers, and filmmakers in Greece who set out to reframe, reassemble, and critically reassess the past from the point of view of the present. This "trouble" has involved reinventing "the past and its remnants" and using ruins and fragments to unsettle or reconfigure cultural archives with "a constant reference to the current sociopolitical state of affairs," while trying to articulate the experience of a different, precarious present (2017, 41, 47, and 49). 
Rethinking ancient ruins thus became part of artistic attempts to articulate the estranging experience of the present. The short documentary film

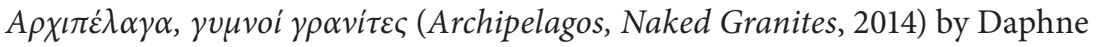
Heretakis is a case in point. ${ }^{5}$ In the film, images of ancient ruins enter new constellations, beyond their monumentalization and museumification, as they are reframed within the Athenian crisis-scape and its newly produced ruins, as well as through the experience of precarious subjects in the present. In the film, the everyday experiences and psychic life of a woman during the crisis are registered through diary entries read in a voiceover while the camera captures fragmentary images of Athens through panoramic shots and close-ups in which monuments and graffiti-covered buildings in a state of ruination take center stage. Interspersed among these images and the accompanying voiceovers are interviews with various Athenians who share their expectations of the present and the future. A group of teenagers are asked: "If you woke up one day and found out the Acropolis wasn't there anymore, what would you think?" And: "What would that mean for Greece?" Their answer- "the loss of our civilization"-confirms the deep-rooted self-conceptualization of modern Greeks through the classical past, inflected by that past's Western European construction as the origin of civilization. This enhances the visual shockeffect of the next scene that shows the Acropolis crumbling and disappearing into a cloud of dust and rubble: an apocalyptic image through which viewers are compelled to imagine the present without this most sacred of ruins that epitomizes the dependency of modern Greece on the classical past. The film thereby joins a series of literary engagements with this unthinkable event-the destruction of the Acropolis or its monuments-which are also discussed in Athina Markopoulou's article in this special section.

Another central scene in the film explores the relationship between ancient statues and present-day subjects by juxtaposing shots of the faces of young people with shots of sculptures from the well-known Antikythera shipwreck. ${ }^{6}$ The statues from this shipwreck were exhibited for the first time in the National Archaeological Museum in Athens in 2012, during the crisis. Besides the sight of broken-off or fragmented body parts, what makes the visual experience of these statues particularly compelling is the way that parts of them have been severely corroded by algae and other marine organisms, giving the impression of a skin disease or serious deformity. In the film, the statues are never shown in their entirety as whole bodies, but only through close-ups that zoom in on the faces or on different body parts (Figures 1 and 2).

When the statues were put on display at the National Archaeological Museum in 2012, some commentators did, indeed, see them as allegories for 

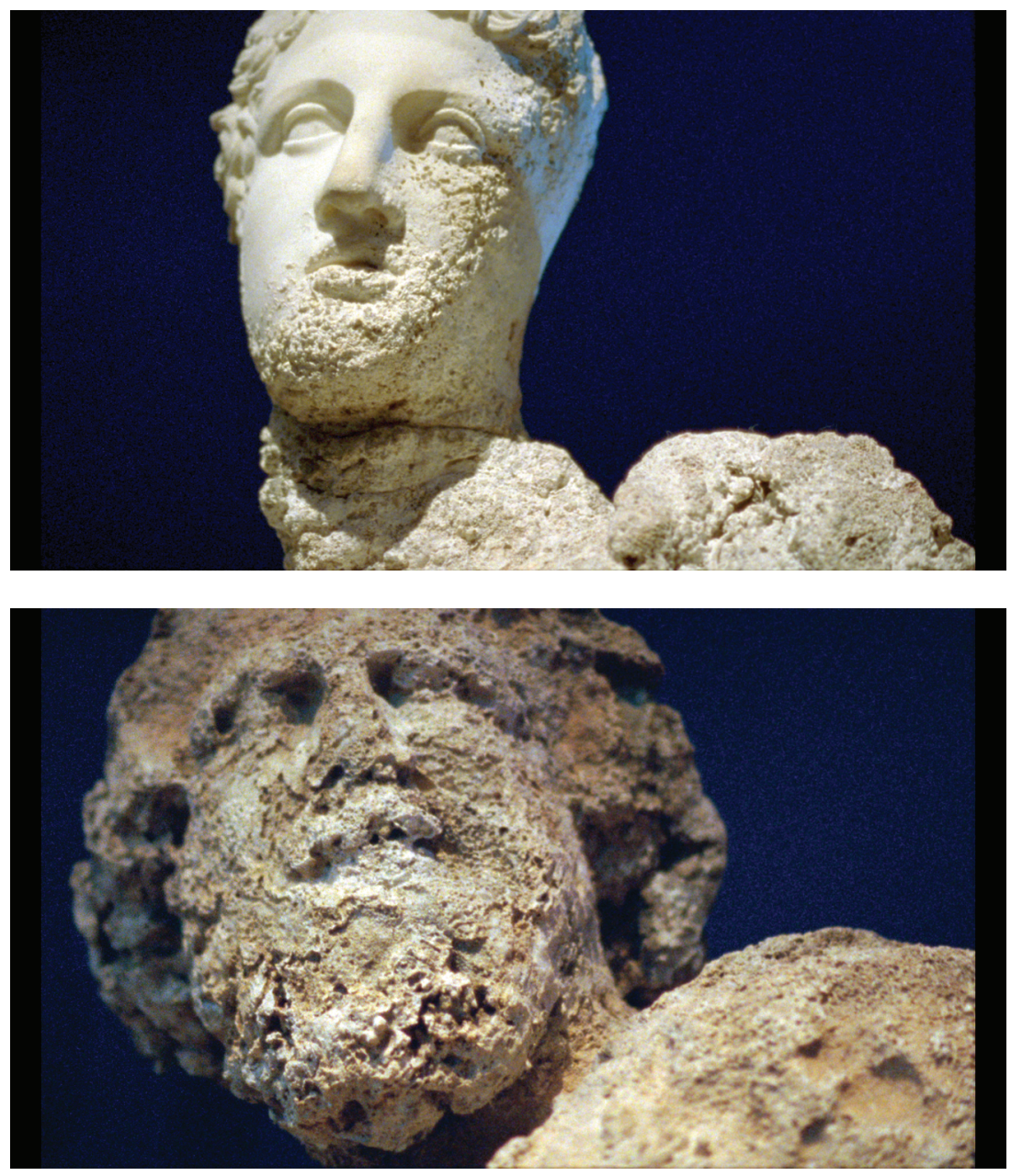

Figures 1, 2. Stills from the documentary film Archipelagos, Naked Granites (2014) by Daphne Heretakis, showing details of sculptures from the Antikythera shipwreck. Images reproduced by permission of the filmmaker.

Greece's crisis-stricken population: as amputated or sick subjects, victims of a violence that has stolen their dignity (Psychoulis 2012). Their exhibition at the museum at that historical moment could thus be seen as mirroring the aforementioned figuration of "mutilation and fragmentation (of statues and temples, of bodies, of the nation)" in cartoons about the crisis, partaking in the "global fascination with the remnants and traces of violence" (Hamilakis 2016, 237). Read in this way, the "deformed" statues are material remnants of 
past violence and lost perfection, which allegorizes the trauma of the present crisis. In a biopolitical allegory of sorts, the crisis figures as a sickness literally registered on the bodies of precarious, dispossessed subjects (the statues), evoking the medical meaning of crisis as illness or disease (Koselleck 2006, 360).

However, in Heretakis's film, in which close-ups of the statues' body parts alternate with shots of young people's faces, the same "naked granites" invite an alternative reading, beyond the tropes of trauma and sickness and the biopolitics of crisis. ${ }^{7}$ The corrosion of the marble testifies to the other lives of these sculptural ruins, which for the longest part of their existence were part of an aquatic ecosystem. The other lives of these ruins, beyond their original context, undercut the perception of classical ruins as timeless or unchanging symbolic capital by drawing attention to their vulnerability to the passage of time and to other environmental forces, and their ability to be transformed when placed in new situations. In the film, the connection between the young people and the statues is premised precisely on this vulnerability and transformability, which admits of other modes of existence beyond trauma or the "disease" of crisis. The corroded, fragmented statues become imperfect but dynamic parts of the present, in an unsettled relationship with contemporary subjects (Boletsi 2018, 12).

Heretakis's parallelisms in this scene evoke, and critically respond to, the Parallelisms photographic project by renowned Greek photographer Nelly (Elli Sougioultzoglou-Seraidari, 1899-1998). Conceived in the late 1920s and developed through the years, Nelly's project paired contemporary Greeks (mostly shepherds and peasant girls) with ancient statues, underscoring their similarities as supposed proof of the racial continuity of Greeks from ancient to modern times (Panayotopoulos 2009, 194; Zacharia 2015, 238). Following a neoclassical aesthetics, the project yielded an image of Hellenic beauty that corresponded with the Western philhellenic gaze (Panayotopoulos 2009). ${ }^{8}$ In Nelly's parallelisms, contemporary Greeks reflect the everlasting nature and aesthetic perfection of Greek forms as captured in ancient statues-a perfection consisting of wholeness, health, eternity, continuity, racial purity, and, as Panayotopoulos argues, “a subconscious quest for 'Aryan' features” $(2009,194)$. By contrast, Heretakis's parallelisms give up the search for formal resemblances; instead, they project imperfection, fragmentation, transformation, and vulnerability as the basis of an open-ended comparison between past and present.

As indexes of an (illusion of) lost wholeness, ruins often function as objects on which melancholic visions or (national, historical) traumas can be projected. The extreme close-ups of the statues' body parts in Heretakis's film disrupt this lost wholeness as an ideal, forcing us to focus instead on the statues' 
materiality and the affective transactions that take place as they interact with contemporary subjects. The illusion of past wholeness and the narratives it supports are also undercut when ruins turn to ashes or when ashes become superimposed on ruins. In hegemonic cultural discourses, ashes, debris, and rubble are not invested with meaning in the same way that revered ruins are. In heritage discourse, monumentalized ruins carry cultural capital and embody established historical and cultural narratives, but they also often conceal the traces of time and of their past destruction(s), turning, as Gastón Gordillo argues, into things without an afterlife or fetishes to be preserved and worshipped (2014, 8-9). By contrast, "the pure multiplicity of rubble is the void that haunts modernity" and causes cultural anxiety $(2014,25)$. Ashes can assume a comparable unsettling function.

How can ashes unsettle the symbolic terrain on which ruins traditionally function and enable alternative narrativizations of ruins? A work that

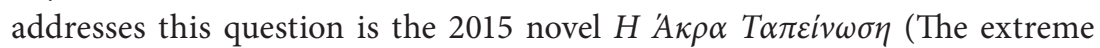
humiliation) by Rea Galanaki, ${ }^{9}$ whose novels are always complex arenas for negotiating history. The plot centers on a night of large-scale anti-austerity protests in 2012 which led to the burning and destruction of several buildings in the center of Athens, including nine buildings-mostly neoclassical-listed as national heritage sites. ${ }^{10}$ In the novel, two elderly women living in a home for senior citizens escape from it on the night of the protests and embark on an adventure that leads them into the heart of the demonstrations and then into the company of homeless people as they roam the streets of Athens for a month until they find their way back home. In the course of their adventure, the city is seen to be haunted by specters of the past-a palimpsest of layers of cultural memory, often accessible through ruins dispersed throughout the city: the ancient past, Byzantium, the German occupation during World War II, the Civil War (1946-1949), the military dictatorship (1967-1974), and the Polytechnic uprising in Athens in 1973.

The fires during the 2012 protests leave everything covered in ashes, upsetting the frame of reference within which past ruins have conventionally been experienced. The narrator wonders: "Can memory be erased by fire, will

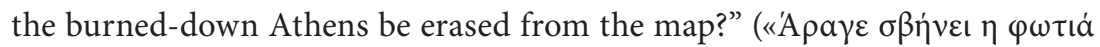

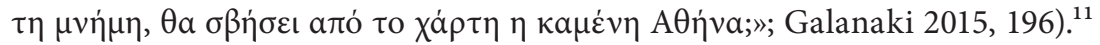
Insofar as the city "had swathed her familiar marble whiteness in a gauze

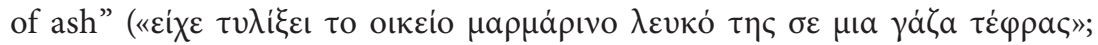
Galanaki 2015, 197), the familiarity of the marble is unsettled and it seemed

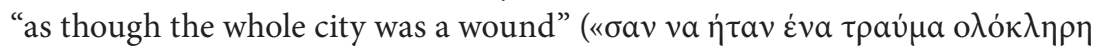
$\eta \pi \dot{0} \lambda \eta »$; ibid.). In this counterintuitive metaphor that casts "ash" ( $\tau \dot{\varepsilon} \varphi \rho \alpha)$ as 
a "gauze" ( $\gamma \dot{\alpha} \zeta \alpha)$ over the city's marble ruins, ashes, which are normally an index of destruction, assume a protective, healing function. The fire and ashes do not end up erasing cultural memory, but they momentarily cover familiar ruins, obscuring the established narratives that accompany them and making space for new understandings of the present, beyond the certainty of fixed past knowledge or the comfort of predictability. One of the novel's protagonists sees herself as a seer, able to tell the future by speaking to familiar ghosts of the past: thus she has changed her given name from Theresia to Teiresia-a selfappellation that turns her into a modern version of Teiresias, the well-known blind prophet of Greek mythology. Lost, however, in an unfamiliar Athens in which the marble of ruins and monuments is eclipsed by ashes and by other, new images, Teiresia feels that her ability to predict the future through the past has dissipated (Galanaki 2015, 77, 144, and 230-231). Meanwhile, as the familiarity of the city and its ruins is disrupted, the other protagonist, Nymfi, rediscovers her passion for painting through her unexpected encounter with Athenian street art-an ephemeral art form that, not unlike the ashes in the story, is superimposed on the city's ruins, making them part of new, fascinating constellations (Galanaki 2015, 234).

This special section teases out the conflicting narratives in which ruins are involved, drawing particular attention to reframings such as those in Heretakis's film and Galanaki's novel, which activate the multiple contemporary lives of ruins. Reframing past ruins through contemporary cultural or social trends often makes them part of creative or critical artistic practices, but it also entails their commodification and involvement in (dark) tourism and processes of gentrification. Art events, creative projects, and artistic interventions have not only appealed to the classical heritage to contemplate the Greek present and reframed that heritage from the point of view of the present; they have also "inhabited" deteriorating and ruined architectural and industrial heritage sites in an attempt to reconfigure the meaning of ruins in a present marked by crisis. Almost every Athens Biennale organized since 2007 has addressed the use and exchange value of abandoned and derelict factories, schools, and hotels, exploring the possibility of their collective use and occupation while also validating, to some extent, the gentrification of former industrial working-class areas as culture-scapes. The main venue for the first Biennale (2007), titled DESTROY ATHENS, was Technopolis, a former gasworks site in Gazi that had been transformed into a cultural venue. The Biennale precipitated the further gentrification of the neighborhood since it took place in the same year as the opening, in the heart of Gazi, of the Keramikos subway station. While the second Biennale, titled HEAVEN (2009), used the abandoned and 
decaying venues of the 2004 Olympic games, the fourth Biennale, AGORA (2013), "occupied" the derelict former Athens Stock Exchange building. The Bageion Hotel, a decaying modernist masterpiece, was first used as a site for workshops during the fifth Athens Biennale, OMONIA (concord) in 2015. Later, during the 2017 Athens Biennale, the former hotel was "inhabited" by a group of Irish and Greek artists, architects, and activists who organized exhibitions and workshops that ranged from theoretical ruminations on architecture as a collective process to discussions of how to design furniture to meet the needs of squatters around Athens (Athens Biennale 2017). Such temporary uses of ruined and abandoned Athenian buildings for art events unquestionably provoke discussions of collective ownership - or the possibility of undermining private ownership, as explored in Kelley Tialiou's contribution to this special section-and of social engagement through creative endeavors. They also, however, undoubtedly promote the image of a hip and cool Athens, branding the city as a so-called alternative tourist site, and potentially detaching its urban ruins from their historical and economic contexts. ${ }^{12}$

\section{Traversing the ruins in the special section}

As guest editors, we began planning this special section on ruins in the spring of 2018, but our ideas took more concrete shape as a result of the workshop "Urban Crisis Spaces: On Walks and Ruins" that we organized with Eva Fotiadi in Amsterdam in May 2019. During this workshop, the intermingled, discrepant functions of urban ruins became a topic of debate: ruins are commodified as visual markers of the Athenian crisis-scape, but they also partake, in Dimitris Plantzos's words, in "an archaeology of the present," "an exploration of the materialities experienced through urban life as a means of rethinking contemporary society and culture" $(2019,119)$.

At the workshop, Efi Giannetopoulou and Thomais Dermati presented an ethnographic research paper ("Athens Calling: The Commodification of a Landscape in Crisis"), which explored the rise of a "graffiti tourism" that enhances the commodification of the ruined walls and abandoned buildings of Athens. Although many works of street art are meant as critiques of poverty, the housing crisis, gentrification, and the injustices of the neoliberal order, Giannetopoulou and Dermati showed how street art can contribute to "the museumification" of ruined Athenian dwellings, turning them into a "tourist attraction" and enhancing the "branding" of Athens as "a poor yet lively city." ${ }^{13}$ In his paper for the same workshop, Dimitris Plantzos also insightfully delineated how street art may in fact recycle and rebrand Greekness into a 
commodity even as it articulates a language that conveys the structural violence that can be traced in the post-crisis urban ecology of Athens. ${ }^{14}$ Plantzos focused particularly on the layered meanings of graffiti by artists such as Achilles, Bleeps, and INO, who re-signify (neo)classical ruins by painting works with classical themes on ruined Athenian buildings with neo-classical facades. Although such works call into question hegemonic representations of Greece, they also partake in the paired contemporary realities of mass touristification on the one hand, and poverty, homelessness, and dispossession on the other.

Alongside such multilayered meanings and materialities in street art, recent works of literature, art, and cinema rethink the relation between past ruins and present subjectivities, explore the affective workings of ruins, or view "ancient ruins through the ruins of the neoliberal order" (Lambropoulos 2018). Athina Markopoulou's article in this special section explores Chris-

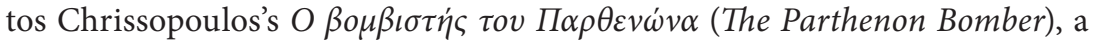
novella originally published in 1996 and revised in 2010. Like Heretakis's film, the novella thematizes the destruction of the Parthenon and its transmutation from a symbol of the classical ideal into present-day debris. Markopoulou contemplates the text's resistance to monumentalization, showing how it blurs the boundaries of fiction and reality and how it imagines the possibility of a New Parthenon after the destruction of this emblematic ruin.

If Markopoulou's contribution reflects on "Hellenism's most sacred site" (Leontis 1995, 10), several other articles in this section highlight ruins that have hitherto been peripheral to Greek national memory or identity. Maria Akritidou's contribution examines another literary recasting of ruins, this time ruins of the Other. Akritidou's article shows how Maro Douka's 2004

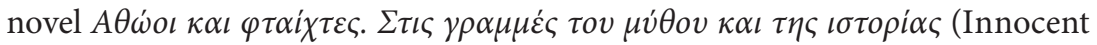
and guilty: along the lines of myth and history) articulates Ottoman ruins in Chania as familial spaces of recognition and remembering, thus staging a common and "shared heritage." At the same time, Akritidou shows how the novel problematizes a relation to the past premised on "family tropes and fixed genealogies." Faidon Moudopoulos-Athanasiou's article similarly explores the life and fate of Ottoman heritage in another site on the national periphery, in Konitsa, this time from a historical and anthropological perspective. Focusing on three monuments-a mosque, an old market and a mansion-Moudopoulos-Athanasiou explores the different stakeholders who shape the divergent discourses around these ruins of the Other.

Helen Vatsikopoulos's contribution on the memoirs of the former residents of abandoned villages in the Prespa region-deserted after the Greek Civil War-adds a new dimension to the idea of ruins as heritage. The memoirs 
studied by Vatsikopoulos reveal the abandoned villages as spaces of forgotten and contested histories, occupying a peripheral position in the memories of a nation. Exploration of the memories and imaginaries associated with this region acquires additional significance given that, in 2018, the region was recalled from national oblivion in order to serve as a site of reconciliation: it was in Prespa that Greece and North Macedonia signed the agreement that resolved the longstanding dispute over the name of the latter nation. Dimitris Papadopoulos's article also looks at Prespa, exploring the multiple and often contradictory ways in which the region's Byzantine remains and ruined villages have been portrayed in films ranging from state-funded television documentaries of the 1960s to more recent productions such as Mı $\alpha \iota \omega v \iota$ í $\eta \tau \alpha \kappa \alpha \iota$ $\mu \iota \alpha \mu \varepsilon \rho \alpha$ (Eternity and A Day) by Theo Angelopoulos (1998) and films about the

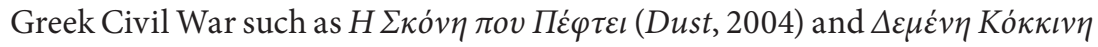

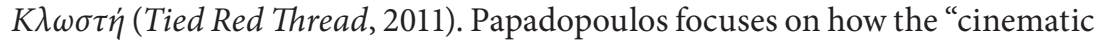
cartography" of Prespa's layered ruin-scape has both maintained nationalist narratives and created subversive possibilities by exposing the multi-layered temporalities of ruination.

All these essays probe ruins both as spaces invested with metaphorical meanings and as material remnants of the past. Yet processes of ruination also involve concrete economics, including the loss and transfer of property: this becomes manifest, for example, in the history of the Prespa villages and in contemporary Athens where the crisis has led to large-scale dispossession. Kelley Tialiou's essay addresses this issue by examining Maria Eichhorn's art project Building as Unowned Property (2017). Can a conceptual artwork transform an abandoned building into unowned property and "a memorial of urban ruination," and could the absence of ownership assume any collective signification? Tialiou situates the implementation of Building as Unowned Property within the larger cultural politics of the documenta 14 Athens/Kassel exhibition in which it was first presented, and delineates the discursive possibilities and limitations involved in Eichhorn's conceptual gesture. Similarly, Eleni Papargyriou's article calls attention to the visual potential for critique in the material remnants of crisis by focusing on Christos Chrissopoulos's trilogy of literary photobooks-Flashlight between the Teeth (2012), The Flâneur's Consciousness (2015), and Land of Anger (2018) - that pair photographs taken in present-day Athens with accompanying text by the author/photographer. Papargyriou explores how the interplay between the text and the images evokes the multi-layered temporality of both ruins and photography. Scrutinizing photography through a Benjaminian lens, Papargyriou's contribution brings out the multi-temporal potentiality of ruins, their continuous mediality, and 
their "nuanced texture as a state in the present which haunts us with its past and looks forward to the future." As these contributions suggest, ruins in cities and in the Greek periphery-in villages and borderlands-may generate multi-temporal and subaltern narratives or radical imaginaries that counter the national narrative of the continuity of Greek history and invite new modes of engaging with archives of the past.

\section{Rebuilding (from) the ruins and the question of futurity}

After the financial and social ruination caused by nearly ten years of crisis, hegemonic narratives of the crisis that called for sacrifices and resilience from citizens have given way to a political vocabulary of recuperation, restoration, and a new start (Boletsi 2020, 269). ${ }^{15}$ The narrative of rebuilding and revival also features in recent representations of Greece in the international press, including accounts of the country's cultural scene. A case in point is the 2018 New York Times article "Athens, Rising," which presents Athens as "emerging from the wreckage as one of Europe's most ... vibrant cultural capitals" (Wilder 2018). It remains to be seen how artistic and cultural production in Greece will respond to this narrative framework of rebuilding from the ruins-or rebuilding the ruins-and whether iconoclastic, provocative, creative responses to ruins, such as those that emerged in the years of the crisis, will continue to be part of the country's cultural life in the years to come.

The narrative of restoration and rebuilding, at least in some of its variations, rests on romanticized, nostalgic constructions of the past or on a conservative neoliberal notion of resilience aimed at "returning to a prior state" (Bracke 2016, 55). Such an understanding of resilience, which involves, as Sarah Bracke argues, "apprehending the future as a cycle of disaster and recovery," undercuts the "capacities of imagining other possible worlds, as well as the agential modalities to pursue those imaginations" (2016, 63-64). Pursuing these imaginings requires that one not rush into thinking beyond the ruins; one must also think the ruins or, in other words, stick with "what people are left with," as Stoler puts it, in order to trace "the social afterlives of [ruined] structures, sensibilities, and things" and their "vital refiguration." At the same time, however, one must not lose sight of the violence, dispossession, and compromised agency that ruins embody and that the verb to ruin captures so succinctly $(2008,194){ }^{16}$

Narratives that foreground the idea of restoration of the ruins left by the crisis are already being challenged as Greece is faced with the new global covid19 crisis and the threat of yet another cycle of crisis and recession. But while 
the so-called new normal of this ongoing global crisis has yet to take shape, the global landscape in which ruins are signified is already radically shifting. Empty streets, eerily silent city centers suddenly tormented by ambulance sirens, deserted office buildings - these form part of the estranging imagery that compels us to see a (dystopian) present as a site of ruins for future ruinologists to explore-or, perhaps, as a newly unfamiliar territory that will allow different visions of futurity to emerge from the ruination caused by this global crisis.

\section{LEIDEN UNIVERSITY AND UNIVERSITY OF AMSTERDAM \\ KOÇ UNIVERSITY, ISTANBUL}

\section{NOTES}

${ }^{1}$ We would like to thank Dimitris Papanikolaou for sharing his article with us prior to its publication, as well as for his comments and feedback on this introduction.

${ }^{2}$ Liakos 2008, 208. Paparrigopoulos's magnum opus, History of the Greek Nation (18601874) involved the "rehabilitation" of the Byzantine period as part of the continuity of Greek history.

${ }^{3}$ For descriptions of Greece by nineteenth-century travelers see, for example, Leontis 1995 and Bastea 1997.

${ }^{4}$ For the ideas presented in this paragraph, see also Boletsi 2018, 7.

${ }^{5}$ For a more extensive version of the analysis of Heretakis's documentary film, see Boletsi 2018, 10-13.

${ }^{6}$ The Antikythera shipwreck is a Roman-era shipwreck from the mid-first century BCE, found near the island of Antikythera.

${ }^{7}$ For Greek artistic responses to the biopolitical present-particularly cinematic ones-see Papanikolaou, forthcoming (a). For uses of classical antiquity as a biopolitical tool in present-day Greece, see Plantzos 2016.

${ }^{8}$ The project accorded with the Western imagination of Greece as well as with the ideology of the Metaxas regime, which promoted the idea of "cultural and racial continuity" between ancient and modern Greeks as a means of asserting the superiority of the Greek race. It gained considerable fame when it was exhibited in the form of giant collages at the Greek Pavilion of the 1939 New York World's Fair (Zacharia 2015, 238). We are grateful to Dimitris Papanikolaou for alerting us to the intertextual link between Heretakis's scene and Nelly's project.

${ }^{9}$ Given the title's ambiguity and religious connotations, an alternative translation of the title would be "The extreme humility."

${ }^{10}$ Among these was the 1870 building housing one of the oldest and most beloved Athenian cinemas, the Attikon.

${ }^{11}$ All translations from Greek sources are by the authors of this article, unless otherwise stated. 
${ }^{12}$ Claire Colomb's study of temporary uses of vacant, derelict, and ruined spaces for art events in Berlin is illuminating for understanding the effects of ad hoc creative events in city marketing. Colomb shows how the EU-funded Urban Catalyst project report, prepared for Berlin in 2003, privileged temporary over permanent art events as a means of promoting the city's creative image: "Temporary uses are often associated with crisis, a lack of vision and chaos. But, despite all preconceptions, examples like the vital scene of Berlin's nomadic clubs or temporary events proves that temporary uses can become an extremely successful, inclusive and innovative part of contemporary urban culture" (Colomb 2012, 131).

${ }^{13}$ The quotations are taken from the abstract of Giannetopoulou and Dermati's paper.

${ }^{14}$ Plantzos's paper was titled "Ruin-Scapes: Rebranding the Classical Present in Post-Crisis Athens." Parts of this paper, including the insights presented here, were incorporated in his editorial for a special issue on Athens in the Journal of Greek Media and Culture (Plantzos 2019).

${ }^{15}$ In his speech celebrating Greece's exit from the bailout program in August 2018, thenPrime Minister Alexis Tsipras, standing against the backdrop of Ithaca's harbor, compared the presumed end of the country's ten-year crisis to the homecoming of Odysseus after a long and troubled journey and hailed the beginning of a new chapter in Greek history (Tsipras 2018). Kyriakos Mitsotakis, Prime Minister of Greece since July 2019, also proclaimed in his victory speech that the country will "proudly raise its head again" under his leadership (iefimerida 2019 [our translation]; see also Boletsi 2020, 267-90).

${ }^{16}$ Stoler cites the following definition of the verb "to ruin" from the Concise Oxford Dictionary: "to inflict or bring great and irretrievable disaster upon, to destroy agency, to reduce to a state of poverty, to demoralize completely" (quoted in Stoler 2008, 194).

\section{REFERENCES CITED}

Avlami, Chrysanthi. 2000. L’Antiquité grecque à la française. Modes d'appropriation de la Grèce au XIXe siècle. Lille: Presses universitaires du Septentrion.

Athens Biennale. 2017. "INHABITING THE BAGEION: Architecture as Critique.” Athens Biennale web site. Accessed 18 May 2020. https://athensbiennale.org/en/inhabiting-the-bageion -architecture-as-critique/.

Bastea, Eleni. 1997. "Nineteenth-Century Travellers in the Greek Lands: Politics, Prejudice, and Poetry in Arcadia." Dialogos: Hellenic Studies Review 4: 47-69.

Boletsi, Maria. 2018. The Futurity of Things Past: Thinking Greece Beyond Crisis. (Inaugural speech, University of Amsterdam). Amsterdam: Amsterdam University Press. Accessed 15 May 2020. http://cf.bc.uva.nl/download/oraties/oraties_2018/Boletsi_Maria.pdf 2020. "Rethinking Stasis and Utopianism: Empty Placards and Imaginative Boredom in the Greek Crisis-Scape.” In Languages of Resistance, Transformation, and Futurity in Mediterranean Crisis-Scapes: From Crisis to Critique, edited by Maria Boletsi, Janna Houwen, and Liesbeth Minnaard, 267-290. Cham: Palgrave Macmillan.

Bracke, Sarah. 2016 "Bouncing Back: Vulnerability and Resistance in Times of Resilience." Vulnerability in Resistance, edited by Judith Butler, Zeynep Gambetti, and Leticia Sabsay, 52-75. Durham, NC and London: Duke University Press.

Bryant, Rebecca. 2010. The Past in Pieces: Belonging in the New Cyprus. Philadelphia: University of Pennsylvania Press. 
Byron, George Gordon, $6^{\text {th }}$ Baron Byron. (1812-1818) 2004. Childe Harold's Pilgrimage. Project Gutenberg. Accessed 20 January 2020. https://www.gutenberg.org/files/5131/5131-h/5131 -h.htm.

Colomb, Claire. 2012. "Pushing the Urban Frontier: Temporary Uses of Space, City Marketing, and The Creative City Discourse in 2000s Berlin." Journal of Urban Affairs 34 (2): 131-152.

Damaskos, Dimitris, and Dimitris Plantzos, eds. 2008. A Singular Antiquity: Archaeology and Hellenic Identity in Twentieth-Century Greece. Athens: Benaki Museum.

DeSilvey, Caitlin, and Tim Edensor. 2012. "Reckoning with Ruins." Progress in Human Geography 37 (4): 465-485.

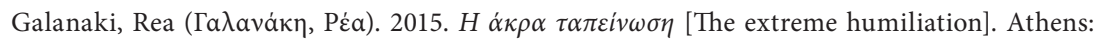
Kastaniotis.

Gordillo, Gastón. 2014. Rubble: The Afterlife of Destruction. Durham, NC: Duke University Press.

Gourgouris, Stathis. 2019. "Xenia-Debt at Home, Debt is Always Foreign." Social Science Information 58 (3): 521-535.

Gumpert, Matthew. 2017. "Beware of Greeks Bearing Gifts: Metaphors as Viruses in Discourses on the Greek Crisis." Journal of Greek Media and Culture 3 (1): 31-51.

Hamilakis, Yannis. 2007. The Nation and Its Ruins: Antiquity, Archeology, and National Imagination in Greece. Oxford: Oxford University Press.

_ 2016. "Some Debts Can Never Be Repaid: The Archaeo-politics of the Crisis." Journal of Modern Greek Studies 34 (2): 27-64.

Hanink, Johanna. 2017. The Classical Debt: Greek Antiquity in an Era of Austerity. Cambridge, MA and London: Harvard University Press.

Herzfeld, Michael. 2002. "The Absent Presence: Discourses of Crypto-Colonialism." South Atlantic Quarterly 101 (4): 899-926.

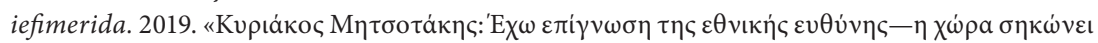

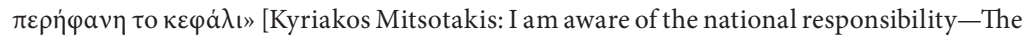
country raises its head proudly]. 7 July. Accessed 5 April 2020. https://www.iefimerida.gr /ekloges/diloseis-kyriakos-mitsotakis-gia-niki-tis-nd.

Koselleck, Reinhart. 2006. "Crisis." Translated by Michaela W. Richter. Journal of the History of Ideas 67 (2): 357-400.

Lambropoulos, Vassilis. 2018. "Neoliberal Austerity and Left Melancholy." Michigan Quarterly Review, 30 April. Accessed 10 April 2020. https://sites.lsa.umich.edu/mqr/2018/04 /neoliberal-austerity-and-left-melancholy-by-vassilis-lambropoulos/.

Leontis, Artemis. 1995. Topographies of Hellenism: Mapping the Homeland. Ithaca, NY: Cornell University Press.

Liakos, Antonis. 2008. "Hellenism and the Making of Modern Greece: Time, Language, Space." In Hellenisms: Culture, Identity, and Ethnicity from Antiquity to Modernity, edited by Katerina Zacharia, 201-236. Aldershot: Ashgate.

Navaro-Yashin,Yael. 2009. "Affective Spaces, Melancholic Objects: Ruination and the Production of Anthropological Knowledge." Journal of the Royal Anthropological Institute 15 (1): 1-18.

Panagopoulos, Iakovos. 2017. "The Issue of the Post-Gender and Transgressive Identities in Contemporary Greek Reality in the Cinematic Work of Panos Koutras." Paper presented at the interdisciplinary conference "Taboo-Transgression-Transcendence in Art \& Science," Corfu, 26 May 2017. Accessed 10 May 2020. https://www.academia.edu/37470092 /The_issue_of_the_post-gender_and_transgressive_identities_in_contemporary_greek _reality_in_the_cinematic_work_of_Panos_Koutras_Full_Paper_. 
Panayotopoulos, Nikos. 2009. “On Greek Photography: Eurocentrism, Cultural Colonialism and the Construction of Mythic Classical Greece." Third Text 23 (2): 181-194.

Papanikolaou, Dimitris. 2011. "Archive Trouble." Society for Cultural Anthropology web site, 26 October. Accessed 15 April 2020. https://culanth.org/fieldsights/archive-trouble.

. 2017. "Archive Trouble, 2017." In Culturescapes Greece/Griechenland: Archeology of the Future/Archäologie der Zukunft, edited by Kateryna Botanova, Christos Chrissopoulos, and Jurriaan Cooiman, 38-51. Basel: Christoph Merian.

. Forthcoming (a). Greek Weird Wave: A Cinema of Biopolitics. Edinburgh: Edinburgh University Press.

. Forthcoming (b). "We are All in Xenialand: Queer Poetics, Citizenship and Hospitality in Panos H. Koutras's Xenia (2014)." In Queering the Migrant in Contemporary European Cinema, edited by James S. Williams. New York: Routledge.

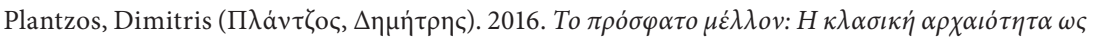

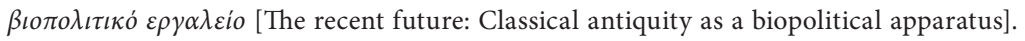
Athens: Nefeli.

2019. “Athens Remains; Still?” Journal of Greek Media and Culture 5 (2): 115-124.

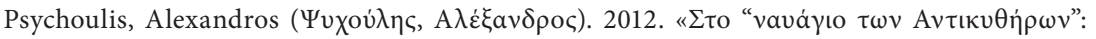

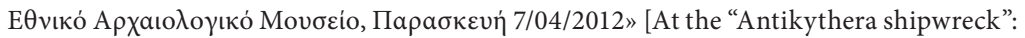
National Archeological Museum, Friday 7/04/2012]. LiFO, 3 May. Accessed 10 April 2020. https://www.lifo.gr/mag/features/3192.

Stoler, Ann Laura. 2008. "Imperial Debris: Reflections on Ruins and Ruination." Cultural Anthropology 23 (2): 191-219.

Talalay, Lauren E. 2013. "Drawing Conclusions: Greek Antiquity, The €conomic Crisis, and Political Cartoons." Journal of Modern Greek Studies 31 (2): 249-276.

Tsipras, Alexis. 2018. "Alexis Tsipras' State Address from Ithaca: 'Today is the Beginning of a New Era." Greek News Agenda, 22 August. Accessed 5 April 2020. http://www.greeknews agenda.gr/index.php/topics/politics-polity/6805.

Tzanelli, Rodanthi, and Maximiliano E. Korstanje. 2016. "Tourism in the European Economic Crisis: Mediatised Worldmaking and New Tourist Imaginaries in Greece.” Tourist Studies 16 (3): 1-19.

Tziovas, Dimitris. 2014. "Introduction: Decolonizing Antiquity, Heritage Politics and Performing the Past." In Re-imagining the Past: Antiquity and Modern Greek Culture, edited by Dimitris Tziovas, 1-26. Oxford: Oxford University Press.

Wilder, Charly. 2018. "Athens Rising." New York Times, 18 June. Accessed 15 April 2020. https:// www.nytimes.com/2018/06/18/travel/athens-after-the-economic-crisis.html.

Yalouri, Eleana. 2001. The Acropolis: Global Fame, Local Claim. London and New York: Routledge. Zacharia, Katerina, ed. 2008. Hellenisms: Culture, Identity, and Ethnicity from Antiquity to Modernity. Aldershot: Ashgate.

2015. "Nelly's Iconography of Greece." In Camera Graeca: Photographs, Narratives, Materialities, edited by Philip Carabott, Yannis Hamilakis, and Eleni Papargyriou, 233-256. Aldershot: Ashgate. 